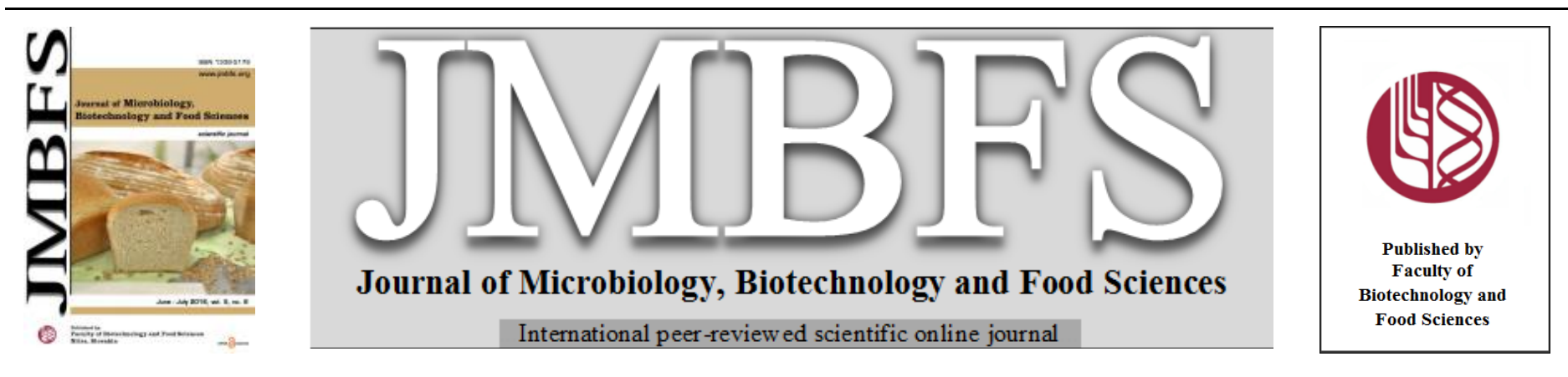

\title{
PRODUCTION OF CELLULASES AND XYLANASE FROM BACILLUS SUBTILIS MU S1 ISOLATED FROM PROTECTED AREAS OF MUNNAR WILDLIFE DIVISION
}

\author{
Sreena C.P ${ }^{1}$, Vimal K.P $P^{2}$ and Denoj Sebastian ${ }^{*^{*}}$ \\ Address(es): Dr. Denoj Sebastian, \\ ${ }^{1}$ Department of Life Sciences, University of Calicut, Malappuram, Kerala- 673635, India. \\ ${ }^{2}$ Department of Botany, University of Calicut, Malappuram, Kerala - 673635, India. \\ *Corresponding author: denojs@gmail.com
}

doi: $10.15414 / j m b f s .2016 .5 .6 .500-504$

\section{ARTICLE INFO}

Received 19. 9. 2015

Revised 31. 12. 2015

Accepted 6.1.2016

Published 1. 6. 2016

\section{Regular article}

open $\partial$ ACcess

\begin{abstract}
The importance of cellulase and xylanase has increased in the current scenario due to their immense biotechnological applications, particularly in biofuel industries. Here, twenty four cellulolytic bacteria were isolated from soils of protected areas under Munnar Wildlife Division, after screening on carboxy methyl cellulose (CMC) agar plates. The isolate with highest zone of clearance $(23 \mathrm{~mm})$ was selected and its xylanolytic capability was confirmed by presence of zone on beechwood xylan agar plate. This Gram positive, spore forming bacterium was identified as Bacillus subtilis based on biochemical characteristics and 16S rRNA gene sequence analysis. The strain has been designated as MU S1 and the gene sequence deposited in Genbank with accession number KT715518. B. subtilis MU S1 showed elevated growth at $40{ }^{\circ} \mathrm{C}$ under agitation. The cellulases and xylanase activities were assayed under the optimum growth condition at every $12 \mathrm{~h}$ interval, upto $48 \mathrm{~h}$. The maximum cellulolytic activities obtained in CMC media were endoglucanase $(0.192$ $\mathrm{U} / \mathrm{ml})$, exoglucanase $(0.149 \mathrm{U} / \mathrm{ml})$, FPase $(0.06 \mathrm{U} / \mathrm{ml})$ at $24 \mathrm{~h}$ and $\beta$-glucosidase $(0.157 \mathrm{U} / \mathrm{ml})$ at $48 \mathrm{~h}$ incubation. The highest xylanase acitivity $(0.28 \mathrm{U} / \mathrm{ml})$ was observed at $36 \mathrm{~h}$ of incubation in media supplemented with beechwood xylan. The potential of $B$. subtilis MU $\mathrm{S} 1$ to produce multiple enzymes makes it a promising nominee for bioconversions and other industrial applications.
\end{abstract}

Keywords: Cellulases, xylanase, 16S rRNA gene, Bacillus subtilis, Munnar Wildlife Division

\section{INTRODUCTION}

The growing concerns about the paucity of fossil fuels, rising cost and air pollution by incomplete combustion of fossil fuels, has resulted in utilization of lignocellulosic biomass as an alternative source of energy (Gaur and Tiwari, 2015). Lignocellulosic biomass is a renewable and inexpensive energy source abundantly available in the environment as forestry, agricultural and agroindustrial wastes. The use of these wastes is however limited by the lack of cost effective hydrolytic enzymes. Significant research, therefore, have been directed towards identification of efficient enzyme producers and designing enzyme cocktail for lignocellulose hydrolysis besides those aimed at metabolic and genetic engineering of existing organisms (Mohanram et al., 2013).

Lignocellulose is mainly composed of three groups of polymers, namely cellulose, hemicellulose, and lignin. Cellulose and hemicellulose are sugar rich fractions of interest for use in fermentation processes, and enzymatic hydrolysis is the most powerful alternative process for the saccharification of these polymers (Sarkar et al., 2012) .Cellulose, an unbranched homopolymer of $\beta-1,4$ linked Dglucose molecules, is the most dominant component of lignocelluloses. The complete degradation of cellulose involves the synergistic action of three hydrolases. First, endo- $\beta-1,4$-glucanases [EC 3. 2. 1.4$]$ nicks the internal cellulose chain, after which exo- $\beta$-1,4-glucanases or cellobiohydrolases [EC 3. 2 . 1. 91] attacks the ends of the crystalline structure and releases cellobiose processively or nonprocessively and finally, $\beta$-1,4-glucosidases [EC 3. 2. 1. 21] cuts cellobiose and cellooligosaccharide to produce glucose (Bhat and Bhat, 1997). Hemicellulose, the second most abundant constituent of lignocellulosic biomass, includes xylan, galactan, mannan, arabinan, and uronic acids (Dodd and Cann, 2009). Xylan, containing $\beta-1$, 4-linked D-xylopyranose residues, is the most abundant of the hemicelluloses. Endo-1, 4- $\beta$-xylanase [EC 3.2.1.8] is the enzyme that cleaves the glycosidic bonds in the xylan backbone, bringing about a reduction in the degree of polymerization of the substrate (Reilly, 1981; Puls and Poutanen, 1989).
Cellulolytic and xylanolytic enzymes are abundantly produced by bacteria, fungi, actinomycetes, protozoa, algae, gastropods, arthropods, nematodes, and so forth (Kuhad et al., 2011; Beg et al., 2001). Generally fungi are better enzyme producers than bacteria but still active research on bacterial enzymes is continuing, because bacteria have a higher growth rate than fungi, leading to greater production of enzymes. Moreover, bacterial enzymes are more efficient biocatalysts and product recovery is much simpler than in case of fungi (Maki $\boldsymbol{e t}$ al., 2009).

Lignocellulolytic enzyme producers have been isolated and characterized from various sources like forest soil (Woo et al.,2014), hot springs (Tamariz-Angeles et al., 2014), composts (Fathallh Eida et al., 2012), dairy manure soil, (Devi and Kumar, 2012) and termites (Dheeran et al., 2012; Sreena et al., 2015). Soil is a rich source of microorganisms harbouring industrially important enzymes. It has a wide array of aerobic lignocellulolytic bacteria, belonging to various phyla including Firmicutes, Actinobacteria, Bacteroidetes, and Proteobacteria. Among them the members of the genus Bacillus, Cellulomonas, Streptomyces, Cytophaga, Cellvibrio, and Pseudomonas have been characterized (Lynd et al., 2002).

Cellulases and xylanases have demonstrated their biotechnological potential in various industries including paper and pulp, agriculture, food, animal feed, brewing and wine making, biomass refining, textile and laundry (Bhat, 2000). However, the most significant application of the enzymes is in the bioconversion of lignocellulosic biomass into fermentable sugars that may be used by yeasts to produce ethanol (Kuhad and Singh, 1993; Zaldivar et al., 2001).

The rising demand for new and competent enzymes has led to the bioprospecting of enzyme producers from less studied environments. The protected areas that come under the jurisdiction of Munnar Wildlife Division are diversity hotspots but little studied and exploited. Therefore, in the present study, we investigated the forest soils from this area as potential source for the isolation of cellulolytic bacteria. The selected isolate was identified and its ability to degrade CMC and xylan by producing multiple enzymes was studied. 


\section{MATERIALS AND METHODS}

\section{Sample collection}

Soil samples were collected in sterile containers from different locations of protected areas under the Munnar Wildlife Division. The protected areas under the jurisdiction of Munnar Wildlife Division are Eravikulam National Park, Chinnar Wildlife Sanctuary and Shola National Parks which include Mathikettan Shola , Anamudi Shola , Pambadum Shola , and the Kurinjimala Sanctuary. The samples were stored at $4{ }^{\circ} \mathrm{C}$ until use.

\section{Enrichment and isolation of cellulase producers}

One gram soil sample was aseptically transferred to $100 \mathrm{ml}$ of sterile CMC (carboxy methyl cellulose) broth and incubated at $37{ }^{\circ} \mathrm{C}$ for 5 days for enrichment of cellulase producing bacteria. The $\mathrm{CMC}$ broth contained the following components in g/L: CMC (10.0), $\mathrm{NaCl}(6.0),\left(\mathrm{NH}_{4}\right)_{2} \mathrm{SO}_{4}(1.0), \mathrm{KH}_{2} \mathrm{PO}_{4}$ (0.5), $\mathrm{K}_{2} \mathrm{HPO}_{4}(0.5), \mathrm{MgSO}_{4}(0.1), \mathrm{CaCl}_{2}(0.1), \mathrm{NaNO}_{3}(0.1)$ and Yeast extract (1.0). The $\mathrm{pH}$ of the medium was adjusted to 7.0. A loopful of the sample from the enriched culture was streaked on CMC agar plates and incubated for about 24-48 h at $37{ }^{\circ} \mathrm{C}$. Isolated colonies were purified by re-streaking on CMC agar plates.

\section{Qualitative screening of cellulase producers}

Cellulase production by the isolated colonies were detected by flooding the streaked plates with congo red solution $(1 \mathrm{mg} / \mathrm{ml}$ in water) for $15 \mathrm{~min}$, and then de-staining with $1 \mathrm{M} \mathrm{NaCl}$ solution for $10-15 \mathrm{~min}$. Potential cellulase producers were selected based on zone of clearance diameter. The one with the highest zone was chosen and studied further. The xylanase producing ability of the isolate was also determined in the similar way using xylan agar plate, which was prepared by replacing CMC in the isolation media with beechwood xylan. Pure culture of the isolate was prepared and stored at $4^{\circ} \mathrm{C}$

\section{Morphological and biochemical characterization}

The selected isolate was subjected to morphological and biochemical tests and identified up to genus level according to Bergey's Manual of Determinative Bacteriology (Bergey et al., 1957). For species identification 16S rRNA gene was analyzed.

\section{Molecular characterization and phylogenetic analysis}

Pure genomic DNA was isolated using XcelGen Bacterial gDNA kit (Cat No: XG2411-01) following manufacturer's protocol. The 16S rRNA gene was amplified from genomic DNA by polymerase chain reaction with two primers: 8F: 5'-AGAGTTTGATCCTGGCTCAG-3' and 1492R: 5'-ACG GCTACCTTGTTACGACTT-3'. The PCR reaction began with initial denaturation at $95^{\circ} \mathrm{C}$ for $2 \mathrm{~min}$, followed by 30 amplification cycles of: primary denaturation at $94{ }^{\circ} \mathrm{C}$ for $30 \mathrm{~s}$, primer annealing at $52{ }^{\circ} \mathrm{C}$ for $30 \mathrm{~s}$ and extension at $72{ }^{\circ} \mathrm{C}$ for $90 \mathrm{~s}$. The final extension was performed at $72{ }^{\circ} \mathrm{C}$ for $10 \mathrm{~min}$ and the product was analyzed using agarose gel electrophoresis to confirm the targeted gene amplification (Singh et al., 2013).

The amplified product was excised from the gel and purified using XcelGen DNA Gel/PCR Purification Mini Kit (Cat No: XG3511-01/3514). The amplicon was sequenced using the BigDye Terminator v3.1 Cycle sequencing Kit (Applied Biosystems, USA) on ABI 3730xl Genetic Analyzer (Applied Biosystems) following manufacturer's instructions. The consensus sequence generated from forward and reverse sequence data using aligner software was used to carry out BLAST with the nr database of NCBI genbank. Based on maximum identity score, best twenty sequences with $99 \%$ to $100 \%$ similarity were selected and a phylogenetic tree was constructed with the candidate strain. Multiple sequence alignment was performed using CLUSTAL W (Thompson et al., 1994) and evolutionary history inferred by the neighbor-joining method (Saitou and Nei, 1987). The evolutionary distances were computed using Kimura 2-parameter method (Kimura, 1980) and phylogenetic analysis was carried out with MEGA 5 (Tamura et al., 2011). Bootstrap resampling analysis for 1000 replicates was performed to estimate the confidence of tree topologies (Felsenstein, 1985) and the tree generated was visualized using FigTree v1.4.2 (Rambaut A, 2014).

\section{Effect of physical parameters on growth}

The growth condition of the isolate was optimized by inoculating it in isolation media and incubating at different temperatures $\left(30{ }^{\circ} \mathrm{C}, 40{ }^{\circ} \mathrm{C}\right.$ and $\left.50{ }^{\circ} \mathrm{C}\right)$ under static and shaker condition $(150 \mathrm{rpm})$. The culture was withdrawn after $24 \mathrm{~h}$ and analyzed for bacterial growth by measuring the absorbance at $650 \mathrm{~nm}$.

\section{Enzyme activity assay}

The crude enzyme for quantitative assay was prepared by inoculating $50 \mathrm{ml}$ of the production media with $1 \%$ starter culture and incubating at $40^{\circ} \mathrm{C}$ for $48 \mathrm{~h}$ in an orbital shaker (150 rpm). CMC and beechwood xylan were used as carbon source in the production media for cellulase and xylanase production respectively. The samples were collected at every $12 \mathrm{~h}$ interval and centrifuged at $10,000 \mathrm{~g}$ for $10 \mathrm{~min}$ to separate the bacterial cells. The supernatants were used as crude enzyme for quantitative assay.

Endoglucanase (CMCase) assay was performed by incubating $1 \mathrm{ml}$ of crude enzyme with equal volume of $1 \% \mathrm{CMC}$ substrate in $0.05 \mathrm{M}$ sodium citrate buffer ( $\mathrm{pH}$ 5.0) for $30 \mathrm{~min}$ at $40{ }^{\circ} \mathrm{C}$. Exoglucanase (avicelase) and $\beta$-glucosidase (cellobiase) activity assays were conducted similarly with $1 \%$ avicel and cellobiose as substrate respectively. Filter paper activity (FPase) assay for total cellulases was carried out using $50 \mathrm{mg}$ strip of Whattman filter paper No. 1 (1 x 6 $\mathrm{cm}$ ) under the same conditions with incubation time of $1 \mathrm{~h}$ (Ghose, 1987). Cellulase activities were calculated by measuring the amount of reducing sugars released by dinitrosalicylic acid (DNS) method (Miller, 1959). All experiments were performed in duplicates and the average was used to assess enzymatic activities of the test isolate. The enzyme activity was determined using calibration curve of glucose. One unit of cellulase activity is defined as the amount of enzyme required to liberate $1 \mu \mathrm{mol}$ of glucose per minute under the assay conditions.

Xylanase activity was assayed using $1 \%$ beechwood xylan with modifications to the protocol of Bailey et al. (1992). The substrate was dissolved in $0.05 \mathrm{M}$ sodium citrate buffer ( $\mathrm{pH} 5.0$ ) and incubated with enzyme for $30 \mathrm{~min}$ at $40{ }^{\circ} \mathrm{C}$. The released reducing sugar was determined as previously mentioned. Xylose was used as standard to prepare calibration curve. One unit of xylanase activity is defined as the amount of enzyme required to liberate $1 \mu \mathrm{mol}$ of xylose per minute under the assay conditions.

\section{RESULTS AND DISCUSSION}

\section{Isolation and screening of enzyme producers}

Soil and the litter horizon contain the largest pool of organic $\mathrm{C}$ in the terrestrial biosphere and hence extracellular enzyme producers thrive in these environments (Magnani et al., 2007). According to the studies of Hatami et al. (2008) total number of bacteria and the number and percentage of cellulolytic bacteria in forest soil samples are more than farming soil. In this study protected areas under Munnar Wildlife Division were explored for novel cellulase producers as there are few reports on isolation of cellulose degraders from this area.

Soil samples were collected from different forests and screened for cellulase producing bacteria, after enrichment in $\mathrm{CMC}$ broth. The samples were rich source of enzyme producers. Although many bacteria were isolated from CMC enriched media, not all of them showed cellulase activity on plate assay. Twenty four colonies displayed visible zone of clearance. Among these, the strain isolated from Eravikulam National Park showed the highest zone $(23 \mathrm{~mm})$ and was selected for further studies. The xylanolytic potential of the strain was tested and confirmed by the presence of zone on xylan supplemented media. The isolate was designated as MU S1.

\section{Identification of strain MU S1}

The colonies of MU S1 on nutrient agar plates were irregular, flat and opaque The isolate was characterized as Gram positive, spore forming motile rod. It gave positive test for Voges-Proskauer, citrate, catalase, oxidase, nitrate reduction and starch hydrolysis whereas negative for indole, methyl red and urease. The 
bacterium could ferment glucose, sucrose and mannitol but not lactose. These results indicated that the strain belonged to genus Bacillus. The predominance of genus Bacillus in soil and waste with high cellulose content has been widely reported (Ulrich and Wirth, 1999; Pourcher et al., 2001). Bacillus strains are well-known for their spore forming ability and production of secondary metabolites like antibiotics. These strategies give them an additional advantage over competitors under conditions of slow growth on cellulosic substrates (Lynd et al., 2002).

In order to reveal the true identity of strain MU S1, molecular and phylogenetic analysis were carried out. The $16 \mathrm{~S}$ rRNA gene was amplified and sequenced. The consensus sequence of 1362 bp generated from forward and reverse sequence data was used for BLAST analysis. The BLAST results revealed $99 \%$ similarity with Bacillus subtilis strain BCX-1 (KM378567.1). A phenogram reflecting the relationship among the strain and candidate sequence of related strains obtained from NCBI database are presented in Figure 1. The phylogenetic analysis displayed close similarity with Bacillus sp. JBP-21 (KM675950.1) and Bacillus subtilis strain LD181 (KJ564129.1). From results of biochemical and molecular analysis the isolate was affirmed to belong to $B$. subtilis. The sequence was deposited in Genbank database with accession number KT715518. Bacillus subtilis strains with cellulolytic and xylanolytic potentials have been isolated from variety of sources like agricultural soil (Kim et al., 2012), water and soil of the Amazon region (Heck et al., 2002), termites (Tarayre et al., 2014), snail (Dar et al., 2015) etc.

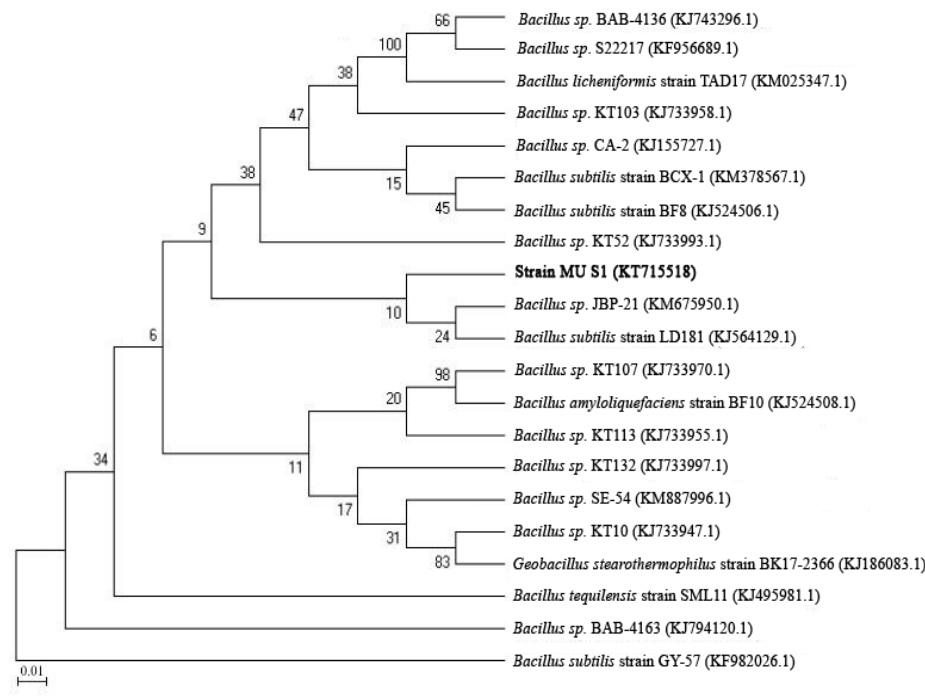

Figure 1 Phylogenetic tree based on 16S rRNA gene sequence, showing relationship between the isolate MU S1 and closely related strains.

\section{Optimization of growth conditions}

Generally, it is found that cell growth and enzyme production are highly correlated (Seo et al., 2013; Singh et al., 2013; Sizova et al., 2011). Physical parameters like temperature and aeration are known to have a significant influence on enzyme production and are critical parameters essential for the success of a fermentation reaction. To find the optimum growth conditions of Bacillus subtilis MU S1, it was grown at different temperatures under static and shaking (150 rpm) conditions (Figure 2). Even though the cultures showed growth at $30{ }^{\circ} \mathrm{C}, 40{ }^{\circ} \mathrm{C}$ and $50{ }^{\circ} \mathrm{C}$ the optimum growth was at $40{ }^{\circ} \mathrm{C}$. This was in accordance with Sethi et al. (2013) who recorded an optimum growth at $40{ }^{\circ} \mathrm{C}$ for Bacillus sp. Jansová et al. (1993) recorded maximum specific growth rate of Bacillus subtilis 115 in the temperature range of $45-48{ }^{\circ} \mathrm{C}$. Temperature was found to regulate enzyme synthesis at mRNA transcription and probably translation levels (Gayda et al., 1985; Kuriki, 1987). It also influences extracellular enzymes secretion, possibly by changing the physical properties of the cell membrane (Yatvin, 1987)

As with temperature, microorganisms also vary in their oxygen requirement. Oxygen acts as a terminal electron acceptor for oxidative reactions to provide energy for all the cellular activities. It was found that the strain MU S1 favored agitation at all temperatures. Agitation is reported to increase the rate of oxygen and nutrient transfer from the liquid medium to the cells. It also prevents bacterial clumps or biofilm formation, ensuring prolific bacterial reproduction (Brown $\boldsymbol{e}$ al., 1987). The result was in agreement with the studies of Deka et al. (2013) and Sanghi et al. (2009) who recorded a positive effect of agitation on growth and enzyme production by Bacillus subtilis.

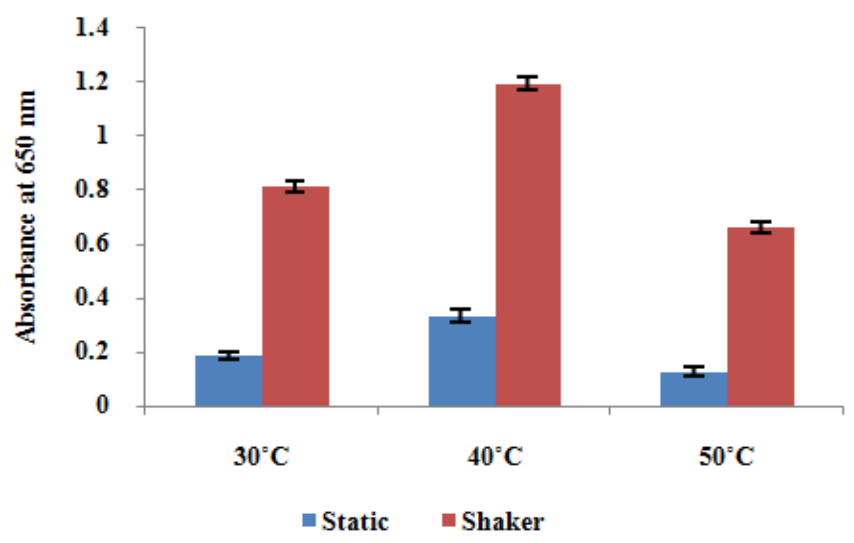

Figure 2 Growth profile of $B$. subtilis strain MU S1 under different conditions after $24 \mathrm{~h}$ incubation. Error bars indicate standard deviation of duplicate observations.

\section{Enzyme activity assay}

The cellulolytic and xylanolytic potential of the strain was examined after inoculating in production media and incubating at $40{ }^{\circ} \mathrm{C}$ in an orbital shaker. The activity was assayed at $12 \mathrm{~h}$ intervals and the results were recorded. It was observed that strain MU S1 very effectively utilized CMC and beechwood xylan for growth by secreting multiple enzymes (endoglucanase, exoglucanase, $\beta$ glucosidase, FPase and xylanase) extracellularly.

Figure 3 shows cellulolytic activity profile obtained during incubation of Bacillus subtilis MU S1 in CMC broth for $48 \mathrm{~h}$. Endoglucanase and exoglucanase activity reached a peak after $24 \mathrm{~h}$ incubation and decreased thereafter. $\beta$ - glucosidase activity which was an exception to this case was found to rise even after $24 \mathrm{~h}$. Similar incubation time was reported in Bacillus subtilis AS3 (Deka et al., 2011) The main reason for decrease of cellulolytic acitivity after $24 \mathrm{~h}$ could be catabolite repression of cellulase genes in the presence of glucose, which is the major end product of cellulose digestion. Another reason for the decrease could be inhibition of endoglucanases and exoglucanases by cellobiose. Also, rapid consumption of cellobiose by $\beta$ - glucosidase leads to glucose accumulation, causing $\beta$-glucosidase product inhibition.

Bacillus subtilis MU S1 exhibited higher endoglucanase activity $(0.192 \mathrm{U} / \mathrm{ml})$ compared to other cellulolytic enzymes. This is in agreement with previous studies which also recorded a CMCase activity greater than exoglucanase, $\beta$ glucosidase and FPase (Pason et al., 2006; Saratale et al., 2012). The endoglucanase activity obtained in the present study was higher than that exhibited by some known natural isolates, for example, Bacillus subtilis AS3 (Deka et al., 2011) isolated from cowdung $(0.07 \mathrm{U} / \mathrm{ml})$; Bacillus amyloliquefaciens SS35 (Singh et al., 2013) isolated from rhinoceros dung $(0.079 \mathrm{U} / \mathrm{ml})$; Brevibacillus sp. DUSELG12 and Geobacillus sp. DUSELR7 (Rastogi et al., 2009) isolated from gold mine $(0.02 \mathrm{U} / \mathrm{ml}$ and $0.058 \mathrm{U} / \mathrm{m}$ respectively).

Exoglucanase activity measured using avicel as substrate was found to reach maximum $(0.149 \mathrm{U} / \mathrm{ml})$ after $24 \mathrm{~h}$ incubation. Similar activity $(0.18 \mathrm{U} / \mathrm{ml})$ was observed by Bacillus licheniformis NLRI X-33 isolated from cow feces (Kim $\boldsymbol{e}$ al., 2004). Generally, avicelase activity is found to be lower than CMCase and $\beta$ glucosidase (Kumar and Parikh, 2015; Waghmare et al., 2014). In a study carried out by Soares et al. (2012) $46.9 \%$ of the isolates displayed the presence of endoglucolytic activity, $9.1 \%$ showed exoglucolytic activity, while only a minority $(4.72 \%)$ could degrade both the substrates on plate assay.

$\beta$-glucosidase (cellobiase) activity of the strain increased beyond $24 \mathrm{~h}$ and then remained almost constant upto $48 \mathrm{~h}$. The highest activity obtained was 0.157 $\mathrm{U} / \mathrm{ml}$. Comparable cellobiase activity has been observed in different Bacillus sp. ( Li et al., 2012; Seo et al., 2014). Our results show some contrast to earlier findings (Kim et al., 2012) in which Bacillus subtilis strains were unable to secrete cellobiase, although its presence was detected in cell debris indicating its membrane association. Kim et al. (2004) also reported lack of extracellular $\beta$ glucosidase in Bacillus licheniformis NLRI X-33. 
FPase (total cellulase) assay performed using filter paper as substrate, measures the ability of crude enzyme to act on both amorphous and crystalline cellulose. Since degradation of filter paper requires the concerted action of endo and exo cellulases, this assay is the best measure of total cellulase activity. The isolate MU S1 displayed highest FPase activity of $0.06 \mathrm{U} / \mathrm{ml}$ after $24 \mathrm{~h}$ incubation. Comparable activities were obtained by Brevibacillus sp. DUSELG12 and Geobacillus sp. DUSELR7 studied by Rastogi et al. (2009). Whereas Ariffin et al. (2006) recorded slightly lower FPase activity $(0.011 \mathrm{U} / \mathrm{ml})$ by Bacillus pumilus EB3.

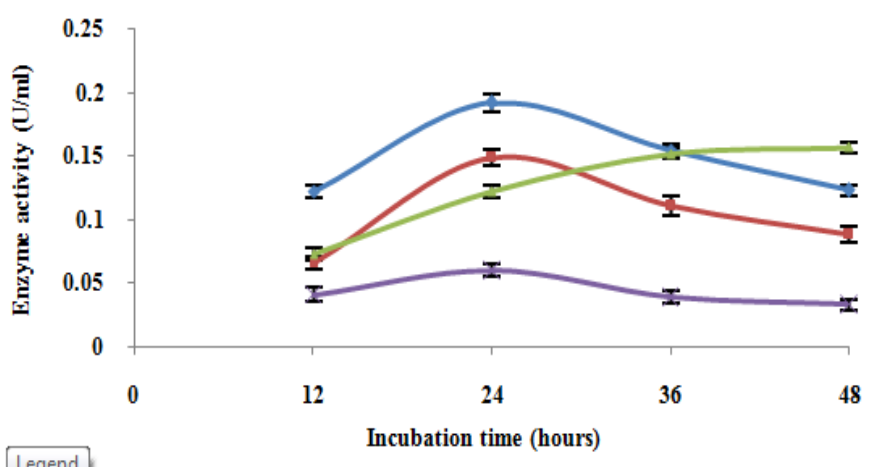

$\longrightarrow$ Endoglucanase

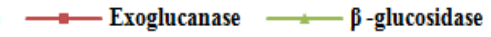

Figure 3 Cellulase activity profile of Bacillus subtilis MU S1.Error bars indicate standard deviation of duplicate observations.

Figure 4 illustrates the xylanase activity profile of $B$. subtilis MU S1 during $48 \mathrm{~h}$ incubation in production media with beechwood xylan as carbon source. Xylanase activity was found to reach a peak at $36 \mathrm{~h}$ with activity of $0.28 \mathrm{U} / \mathrm{m}$ and decreased subsequently. In congruence with our findings, many previous studies have also indicated xylanase activity from cellulolytic Bacillus $s p$. As in many studies cited earlier, (Heck et al., 2002; Pajni et al., 1989; Ali et al., 2013) xylanase activity of strain MU S1 was found to be higher than the corresponding CMCase activity. However, results with greater CMCase activities have also been documented (Seo et al., 2013).

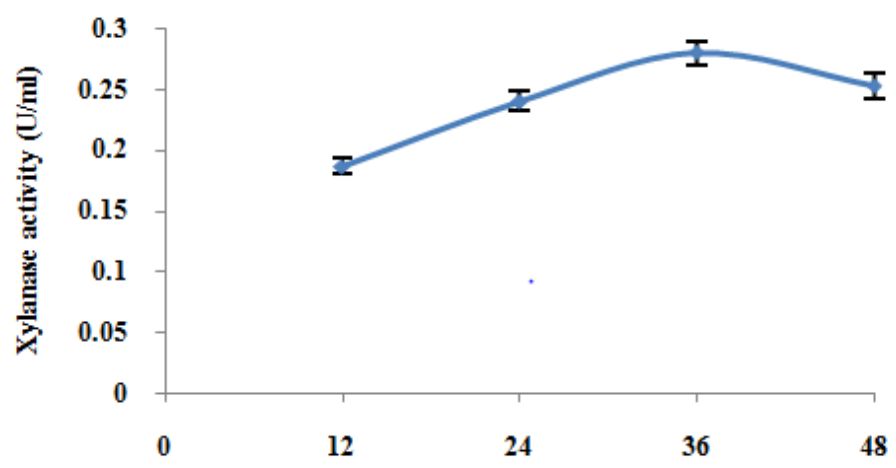

Incubation time (hours)

Figure 4 Xylanase activity profile of Bacillus subtilis MU S1. Error bars indicate standard deviation of duplicate observations.

\section{CONCLUSION}

The ever-increasing demand for highly competent enzymes has accelerated the search for novel enzyme producers from unexplored environments. In the present investigation we were successful in isolating twenty four cellulose degrading bacteria from the protected forests of Munnar Wildlife Division. These unexplored areas were definitely an affluent source of cellulase producers. The best bacterial isolate selected based on zone diameter, was characterized and identified as Bacillus subtilis. This isolate designated as Bacillus subtilis MU S1(accession no. KT715518) displayed elevated growth at $40{ }^{\circ} \mathrm{C}$ under agitation condition. The strain produced promising levels of cellulases (endoglucanase, exoglucanase, $\beta$-glucosidase, FPase) and xylanase. The ability of the isolate MU $\mathrm{S} 1$ to produce multiple enzymes makes it a prospective candidate for a variety of industrial applications mainly biofuel industry. The efficiency of the isolate can be further improved by media optimization and genetic modifications.

\section{REFERENCES}

Ali, S. M., Omar, S. H., \& Soliman, N. A. (2013). Co-production of cellulase and xylanase enzymes by thermophilic Bacillus subtilis 276NS. International Journal of Biotechnology for Wellness Industries, 2(2), 65-74.

Ariffin, H., Abdullah, N., Umi Kalsom, M.S., Shirai, Y., \& Hassan, M.A. (2006) Production and characterization of cellulase by Bacillus pumilus EB3. International Journal of Engineering and Technology, 3(1), 47-53.

Bailey, M. J., Biely, P., \& Poutanen, K. (1992). Interlaboratory testing of methods for assay of xylanase activity. Journal of Biotechnology, 23(3), 257-270. http://dx.doi.org/10.1016/0168-1656(92)90074-j

Beg, Q. K., Kapoor, M., Mahajan, L., \& Hoondal, G. S. (2001). Microbial xylanases and their industrial applications: a review. Applied Microbiology and Biotechnology, 56(3-4), 326-338. http://dx.doi.org/10.1007/s002530100704

Bergey, D. (1957). Manual of Determinative Bacteriology. American Society for Microbiology. Williams \& Willkins Co. Publishers, Baltimore, USA, VII Edition.

Bhat, M. K. (2000). Cellulases and related enzymes in biotechnology. Biotechnology Advances, 18(5), 355-383. http://dx.doi.org/10.1016/S0734 9750(00)00041-0

Bhat, M. K., \& Bhat, S. (1997). Cellulose degrading enzymes and their potential industrial applications. Biotechnology Advances, 15(3-4), 583-620. http://dx.doi.org/10.1016/s0734-9750(97)00006-2

Brown, C. M., Campbell, I., \& Priest, F. G. (1987). Introduction to biotechnology. Vol (10) Oxford Oxfordshire ; Boston: Blackwell Scientific Publications.

Dar, M. A., Pawar, K. D., Jadhav, J. P., \& Pandit, R. S. (2015). Isolation of cellulolytic bacteria from the gastro-intestinal tract of Achatina fulica (Gastropoda: Pulmonata) and their evaluation for cellulose biodegradation. International Biodeterioration \& Biodegradation, 98, 73-80. http://dx.doi.org/ 10.1016/j.ibiod.2014.11.016

Deka, D., Bhargavi, P., Sharma, A., Goyal, D., Jawed, M., \& Goyal, A. (2011). Enhancement of cellulase activity from a new strain of Bacillus subtilis by medium optimization and analysis with various cellulosic substrates. Enzyme Research, 2011, 1-8. http://dx.doi.org/ 10.4061/2011/151656

Deka, D., Das, S. P., Sahoo, N., Das, D., Jawed, M., Goyal, D., \& Goyal, A (2013). Enhanced cellulase production from Bacillus subtilis by optimizing physical parameters for bioethanol production. ISRN Biotechnology, 2013, 1-11 http://dx.doi.org/10.5402/2013/965310

Devi, M. C., \& Kumar, M. S. (2012). Isolation and screening of lignocellulose hydrolytic saprophytic fungi from dairy manure soil. Annals of Biological Research,3(2), 1145-1152.

Dheeran, P., Nandhagopal, N., Kumar, S., Jaiswal, Y. K., \& Adhikari, D. K (2012). A novel thermostable xylanase of Paenibacillus macerans IIPSP3 isolated from the termite gut. Journal of Industrial Microbiology and Biotechnology, 39(6), 851-860. http://dx.doi.org/10.1007/s10295-012-1093-1

Dodd, D., \& Cann, I. K. O. (2009). Enzymatic deconstruction of xylan for biofuel production. Global Change Biology Bioenergy, 1(1), 2-17. http://dx.doi.org/10.1111/j.1757-1707.2009.01004.x

Fathallh Eida, M., Nagaoka, T., Wasaki, J., \& Kouno, K. (2012). Isolation and characterization of cellulose-decomposing bacteria inhabiting sawdust and coffee residue composts. Microbes and Environments, 27(3), 226-233. http://dx.doi.org/ 10.1264/jsme2.ME11299

Felsenstein, J. (1985). Confidence limits on phylogenies: An approach using the bootstrap. Evolution, 39(4), 783-791. http://dx.doi.org/ 10.2307/2408678

Gaur, R., \& Tiwari, S. (2015). Isolation, production, purification and characterization of an organic-solvent-thermostable alkalophilic cellulase from Bacillus vallismortis RG-07. BMC Biotechnology, 15(19),1-12. http://dx.doi.org/10.1186/s12896-015-0129-9

Gayda, R. C., Stephens, P. E., Hewick, R., Schoemaker, J. M., Dreyer, W. J., \& Markovitz, A. (1985). Regulatory region of the heat shock-inducible capR (lon) gene: DNA and protein sequences. Journal of Bacteriology, 162(1), 271-275. PMCID: PMC218984

Ghose, T. K. (1987). Measurement of cellulase activities. Pure and Applied Chemistry, 59(2), 257-268. http://dx.doi.org/ 10.1351/pac198759020257

Hatami, S., Alikhani, H.A., Besharati, H., Salehrastin, N., Afrousheh, M., \& Yazdani Jahromi, Z. (2008). Investigation on aerobic cellulolytic bacteria in some of north forest and farming soils. American-Eurasian Journal of Agricultural and Environmental Sciences, 3(5), 713-716.

Heck, J. X., Hertz, P. F., \& Ayub, M. A. Z. (2002). Cellulase and xylanase productions by isolated Amazon Bacillus strains using soybean industrial residue based solid-state cultivation. Brazilian Journal of Microbiology, 33(3), 213-218. http://dx.doi.org/10.1590/S1517-83822002000300005

Jansová, E., Schwarzová, Z., \& Chaloupka, J. (1993). Sporulation and synthesis of extracellular proteinases in Bacillus subtilis are more temperature-sensitive 
than growth. Folia Microbiologica, 38(1), 22-24. http://dx.doi.org/10.1007/bf02814543

Kim, T. I., Jeong, K. H., Ham, J. S., Yang, C. B., Chung, I. B., Kim, M. K., \& Kim, K. N. (2004). Isolation and characterization of cellulase secreting bacterium from cattle manure: Application to composting. Compost Science \& Utilization, 12(3), 242-248. http://dx.doi.org/10.1080/1065657x.2004.10702189

Kim, Y.-K., Lee, S.-C., Cho, Y.-Y., Oh, H.-J., \& Ko, Y. H. (2012). Isolation of cellulolytic Bacillus subtilis strains from agricultural environments. ISRN Microbiology, 2012, 1-9. http://dx.doi.org/10.5402/2012/650563

Kimura, M. (1980). A simple method for estimating evolutionary rates of base substitutions through comparative studies of nucleotide sequences. Journal of Molecular Evolution, 16(2), 111-120. PMID:7463489

Kuhad, R. C., Gupta, R., \& Singh, A. (2011). Microbial cellulases and their industrial applications. Enzyme Research, 2011, 1-10. http://dx.doi.org/ $10.4061 / 2011 / 280696$

Kuhad, R. C., \& Singh, A. (1993). Lignocellulose biotechnology: Current and future prospects. Critical Reviews in Biotechnology, 13(2), 151-172. http://dx.doi.org/10.3109/07388559309040630

Kumar, A. K., \& Parikh, B. S. (2015). Cellulose-degrading enzymes from Aspergillus terreus D34 and enzymatic saccharification of mild-alkali and diluteacid pretreated lignocellulosic biomass residues. Bioresources and Bioprocessing, 2(1), 1-13. http://dx.doi.org/10.1186/s40643-015-0038-8

Kuriki, Y. (1987). Heat shock inactivates a supernatant factor(s) specifically required for efficient expression of the amp gene in Escherichia coli. FEBS Letters, 223(1), 127-130. http://dx.doi.org/10.1016/0014-5793(87)80522-7

Li, S-B., Ren-Chao, Z., Li, Xia., Chen, C-Y., \& Yang, A-L (2012). Solid-state fermentation with okara for production of cellobiase-rich cellulases preparation by a selected Bacillus subtilis Pa5. African Journal of Biotechnology, 11(11), 2720-2730. http://dx.doi.org/10.5897/AJB11.2850

Lynd, L. R., Weimer, P. J., van Zyl, W. H., \& Pretorius, I. S. (2002). Microbia cellulose utilization: fundamentals and biotechnology. Microbiology and $\begin{array}{llll}\text { Molecular Biology } & \text { Reviews, } & 66(3), & 506-577 .\end{array}$ http://dx.doi.org/10.1128/MMBR.66.3.506-577.2002

Magnani, F., Mencuccini, M., Borghetti, M., Berbigier, P., Berninger, F., Delzon, S., . . \& Grace, J. (2007). The human footprint in the carbon cycle of temperate and boreal forests. Nature, 447(7146), 849-851. http://dx.doi.org/10.1038/nature05847

Maki, M., Leung, K. T., \& Qin, W. (2009). The prospects of cellulase-producing bacteria for the bioconversion of lignocellulosic biomass. International Journal of Biological Sciences, 5(5), 500-516. http://dx.doi.org/10.7150/ijbs.5.500

Miller, G. L. (1959). Use of dinitrosalicylic acid reagent for determination of reducing sugar. Analytical Chemistry, 31(3), 426-428. http://dx.doi.org/10.1021/ac60147a030

Mohanram, S., Amat, D., Choudhary, J., Arora, A., \& Nain, L. (2013). Novel perspectives for evolving enzyme cocktails for lignocellulose hydrolysis in biorefineries. Sustainable Chemical Processes, l(1), 15. http://dx.doi.org/10.1186/2043-7129-1-15

Pajni, S., Dhillon, N., Vadehra, D. V., \& Sharma, P. (1989). Carboxymethyl cellulase, $\beta$-glucosidase and xylanase production by Bacillus isolates from soil. International Biodeterioration, 25(1-3), 1-5. http://dx.doi.org/10.1016/02653036(89)90022-5

Pason, P., Kyu, K. L., \& Ratanakhanokchai, K. (2006). Paenibacillus curdlanolyticus strain B-6 xylanolytic-cellulolytic enzyme system that degrades insoluble polysaccharides. Applied and Environmental Microbiology, 72(4), 2483-2490. http://dx.doi.org/10.1128/aem.72.4.2483-2490.2006

Pourcher, A., Sutra, L., Hebe, I. I., Moguedet, G., Bollet, C., Simoneau, P., \& Gardan, L. (2001). Enumeration and characterization of cellulolytic bacteria from refuse of a landfill. FEMS Microbiology Ecology, 34(3), 229241. http://dx.doi.org/10.1111/j.1574-6941.2001.tb00774.x

Puls J \& Poutanen K. (1989). Mechanisms of enzymatic hydrolysis of hemicelluloses (xylans) and procedures for determination of the enzyme activities involved. In: Ericksson KEE, Ander P (eds) Proceedings of the 3rd International Conference on Biotechnology in the Pulp and Paper Industry. STFI, Stockholm, pp 93-95

Rambaut A. (2014). FigTree, a graphical viewer of phylogenetic trees, v1.4.2. Institute of Evolutionary Biology, University of Edinburgh. http://tree.bio.ed.ac. uk/software/figtree/

Rastogi, G., Muppidi, G. L., Gurram, R. N., Adhikari, A., Bischoff, K. M., Hughes, S. R., . . . \& Sani, R. K. (2009). Isolation and characterization of cellulose-degrading bacteria from the deep subsurface of the Homestake gold mine, Lead, South Dakota, USA. Journal of Industrial Microbiology and Biotechnology, 36(4), 585-598. http://dx.doi.org/10.1007/s10295-009-0528-9

Reilly, P.J. (1981) Xylanases, structure and function. In:Trends in the biology of fermentation for fuels and chemicals (A Hollaender ed). Plenum press, New York, pp 111-129

Saitou, N., \& Nei, M. (1987). The neighbor-joining method: a new method for reconstructing phylogenetic trees. Molecular Biology and Evolution, 4(4), 406425. PMID:3447015
Sanghi, A., Garg, N., Kuhar, K., Kuhad, R. C., \& Gupta, V.K. (2009). Enhanced production of cellulase-free xylanase by alkalophilic Bacillus subtilis ash and its application in biobleaching of kraft pulp. BioResources, 4(3), 1109-1129.

Saratale, G. D., Saratale, R. G., \& Oh, S. E. (2012). Production and characterization of multiple cellulolytic enzymes by isolated Streptomyces $s p$. MDS. Biomass and Bioenergy, 47, 302-315. http://dx.doi.org/10.1016/j.biombioe.2012.09.030

Sarkar, N., Ghosh, S. K., Bannerjee, S., \& Aikat, K. (2012). Bioethanol production from agricultural wastes: An overview. Renewable Energy, 37(1), 1927. http://dx.doi.org/10.1016/j.renene.2011.06.045

Seo, J., Park, T. S., Kim, J. N., Ha, J. K., \& Seo, S. (2014). Production of endoglucanase, beta-glucosidase and xylanase by Bacillus licheniformis grown on minimal nutrient medium containing agriculture residues. Asian-Australasian $\begin{array}{lll}\text { Journal of Animal } & \text { Sciences, } & \text { 27(7), 946-950 }\end{array}$ http://dx.doi.org/10.5713/ajas.2014.14082

Seo, J. K., Park, T. S., Kwon, I. H., Piao, M. Y., Lee, C. H., \& Ha, J. K. (2013). Characterization of cellulolytic and xylanolytic enzymes of Bacillus licheniformis JK7 isolated from the rumen of a native Korean goat. Asian-Australasian Journal of Animal Sciences, 26(1), 50-58. http://dx.doi.org/10.5713/ajas.2012.12506 Sethi, S., Datta, A., Gupta, B. L., \& Gupta, S. (2013). Optimization of cellulase production from bacteria isolated from soil. ISRN Biotechnology, 2013, 1-7. http://dx.doi.org/10.5402/2013/985685

Singh, S., Moholkar, V. S., \& Goyal, A. (2013). Isolation, identification, and characterization of a cellulolytic Bacillus amyloliquefaciens strain SS35 from rhinoceros dung. ISRN Microbiology, 2013, 1-7. http://dx.doi.org/10.1155/2013/728134

Sizova, M. V., Izquierdo, J. A., Panikov, N. S., \& Lynd, L. R. (2011). Celluloseand xylan-degrading thermophilic anaerobic bacteria from biocompost. Applied and Environmental Microbiology, 77(7), 2282-2291. http://dx.doi.org/10.1128/aem.01219-10

Soares, F. L., Melo, I. S., Dias, A. C., \& Andreote, F. D. (2012). Cellulolytic bacteria from soils in harsh environments. World Journal of Microbiology and Biotechnology, 28(5), 2195-2203. http://dx.doi.org/10.1007/s11274-012-1025-2 Sreena, C.P., Resna, N.K., \& Sebastian, D. (2015). Isolation and characterization of cellulase producing bacteria from the gut of termites (Odontotermes and Heterotermes species). British Biotechnology Journal, 9(1), 1-10. http://dx.doi.org/10.9734/bbj/2015/20001

Tamariz-Angeles, C., Olivera-Gonzales, P., Villena, G. K., \& Gutiérrez-Correa, M. (2014). Isolation and identification of cellulolytic and xylanolytic bacteria from Huancarhuaz hot spring, Peru. Annual Research \& Review in Biology, 4(19), 2920-2930. http://dx.doi.org/ 10.9734/ARRB/2014/10699

Tamura, K., Peterson, D., Peterson, N., Stecher, G., Nei, M., \& Kumar, S. (2011) MEGA5: Molecular evolutionary genetics analysis using maximum likelihood, evolutionary distance, and maximum parsimony methods. Molecular Biology and Evolution, 28(10), 2731-2739. http://dx.doi.org/ 10.1093/molbev/msr121

Tarayre, C., Brognaux, A., Bauwens, J., Brasseur, C., Matteotti, C., Millet, C., . \& Thonart, P. (2014). Isolation of amylolytic, xylanolytic, and cellulolytic microorganisms extracted from the gut of the termite Reticulitermes santonensis by means of a micro-aerobic atmosphere. World Journal of Microbiology and Biotechnology, 30(5), 1655-1660. http://dx.doi.org/10.1007/s11274-013-1585-9 Thompson, J. D., Higgins, D. G., \& Gibson, T. J. (1994). CLUSTAL W: improving the sensitivity of progressive multiple sequence alignment through sequence weighting, position-specific gap penalties and weight matrix choice. Nucleic Acids Research, 22(22), 4673-4680. PMID:7984417.

Ulrich, A., \& Wirth, S. (1999). Phylogenetic diversity and population densities of culturable cellulolytic soil bacteria across an agricultural encatchment. Microbial Ecology, 37(4), 238-247. http://dx.doi.org/10.1007/s002489900146

Waghmare P. R. , Kshirsagar, S. D., Saratale, R. G., Govindwar, S. P., \& Saratale, G. D. (2014). Production and characterization of cellulolytic enzymes by isolated Klebsiella $s p$. PRW-1 using agricultural waste biomass. Emirates Journal of Food and Agriculture, 26(1), 44-59. http://dx.doi.org/10.9755/ejfa.v26i1.15296

Woo, H. L., Hazen, T. C., Simmons, B. A., \& DeAngelis, K. M. (2014). Enzyme activities of aerobic lignocellulolytic bacteria isolated from wet tropical fores soils. Systematic and Applied Microbiology, 37(1), 60-67. http://dx.doi.org/10.1016/j.syapm.2013.10.001

Yatvin, M. B. (1987). Influence of membrane-lipid composition on translocation of nascent proteins in heated Escherichia coli. Biochimica et Biophysica Acta, 901(1), 147-156. http://dx.doi.org/10.1016/0005-2736(87)90266-5

Zaldivar, J., Nielsen, J., \& Olsson, L. (2001). Fuel ethanol production from lignocellulose: a challenge for metabolic engineering and process integration. Applied Microbiology and Biotechnology, 56(1-2), 17-34 http://dx.doi.org/10.1007/s002530100624 